TIGG Vol.2 No.8 (1990)

G.YOOIOPIC (TIGG-11/02/90-GT-5)

\title{
Receptors for Gangliosides on Myelin-associated Membranes of the Rat Central Nervous System
}

Michael TIEMEYER, Patti SWANK-HIIL, and Ronald L. SCHNAAR

J. Biol. Chem. (1990) 265, 11990-11999

That gangliosides regulate cellular functions has been indicated in many reports, while the mechanism by which gangliosides become bound to cellular membrane and generate intracellular events are not well understood. Gangliosides may possibly approach and subsequently be incorporated into cellular membranes by lipid moieties, or they may bind to complementary molecules on the cell surface. A method was developed to assess the ability of glycosphingolipid to mediate cell functions through interactions with the corresponding cell surface receptors by incubating cells in plastic microwells preadsorbed with various glycolipids (Blackburn, C. C. and Schnaar, R. L. (1983) J. Biol. Chem. 258, 1180-1188]. Rapid and specific adhesion of neural retina cells to the well surfaces on which gangliosides had been adsorbed was observed. Protease treatment of neural retina cells reduced ganglioside-specific cell adhesion [Blackburn, C. C., Swank-Hill, P. and Schnaar, R. L. (1986) J. Biol. Chem. 261, 2873-2881 ]. Complementary ganglioside binding protein on cell membranes thus appears to be a possibility. A radioligand, $125 \mathrm{I}-$ $\left(G_{T 1 b}\right)_{n} B S A$, was synthesized by derivatizing gangliosides covalently to carrier proteins, bovine serum albumin (BSA), via their lipid moieties. The radioligands were used as probes to search for brain ganglioside receptors. A ganglioside-specific binding protein was detected on the detergent-solubilized crude brain membranes of SpragueDawley rat and was found to possess high affinity and saturable binding activity for ${ }^{125} \mathrm{I}-\left(\mathrm{G}_{\mathrm{T} 1 \mathrm{~b}}\right)_{4}{ }^{\mathrm{BSA}}$ and be trypsin sensitive [Tiemeyer, M., Yasuda, Y. and Schnaar, R. L. (1989) J. Biol. Chem. 264, 1671-1681]. 125I$\left(\mathrm{G}_{\mathrm{T} 1 \mathrm{~b}}\right)_{\mathrm{n}} \mathrm{BSA}$ binding to brain membranes was blocked by ganglioside GQ1b, GT1b and $G_{D 1 b}$ in low concentration and reduced by treatment of $125 \mathrm{I}-\left(\mathrm{G}_{\mathrm{T} 1 \mathrm{~b}}\right){ }_{4} \mathrm{BSA}$ with neuraminidase. Other gangliosides, examined such as neutral glycosphingolipids, sphingosine and glycoproteins inhibited binding when present at much higher concentrations.

This paper is a continuation of a study on the subcellular distribution, regional distribution, and developmental expression of the ganglioside receptors in rat brain. Membranes prepared from different anatomical regions of the central nervous system (CNS) demonstrated various degrees of radioligand binding activity, directly related to the abundance of white mater. This tissue-specific distribution of binding activity was also confirmed by autoradiography of tissue sections with white tracts, including corticospinal spinothalamic, 


\section{中枢神怪ミエリンに局在するガンクリオシド秥合蛋白買}

ガングリオシドはその命名の由来からも判 るように、高等動物の神経系に非常に多いシ アル酸を含むスフィンゴ榶脂質である。ガン グリオシドはその糖鎖を細胞外に笑き出して、 その脂質部分を形質膜に埋め込んで存在する と考えられている。神経細胞に多いガングリ オシドは、一体そこで何をやっているのだろ

う？ 細胞間の相互作用が分子間相互作用を 介するなら、糖鎖を介する反応として誰です 糖特異的結合タンパク質 (レクチン) をすぐ に思い付く。それで、ガングリオシドにもそ れを特異的に認識する相補的な分子が存在す るのではないかと、今までに幾つもの研究が なされている。その中でも、最も説得性の高 いのはSchnaarらの研究である [Tiemeyer, M. , Yasuda, Y., and Schnaar, R. L. (1989) J. Biol. Chem. 264. 1671-1681]。彼らは4モ ルのGT1bをその脂質部分を介して 1 モルの BSAに結合させたリガンドを ${ }^{125}$ Iで標識し、こ れをプローブとして、ラットの脳の全膜画分 中のポリビニリデンジフルオライド膜に吸着 する特に親脂性物質に、これと結合する性質 があるのを見出してガングリオシドレセプタ 一と呼んだのである。本論文は、この著者達 がこのレセプター（つまり、ガングリオシド 結合タンパク質）の精製はさておき、その局 在性を調べたものである [Tiemeyer, M. . Swank-Hill, P., and Schnaar, R.L. (1990)
J. Biol. Chem. 265, 11990-11999] 。

彼らは先に夆いたように ${ }^{125}$ I-(GT1b) 4 -BSA というプロープとの結合を調べるやり方で、 脳組織のホモジェネートを遠心法で分画し、 細胞内のどの画分にこの結合性があるか、追 いっめていった。すると、それはミエリン膜 を多く含む部分であって、シナプトソームや ミトコンドリア、核といった部分ではなかっ た。この分画には、オリゴデンドログリアの ミエリン膜と、ミエリンで包まれた軸索部分 が含まれていたが、この二者を密度勾配遠心 法で分画すると、軽い方に分画されたミエリ ン膜の方に結合性が回収されたのである。非 常に興味媣いことに、同じミエリンでも中枢 神経系(CNS)のミエリンはこのレセプタ一を含 むが、末梢神経系(PNS)のミエリン膜にはこれ は僅かしか含まれていなかった。

ミエリン塩基性タンパク質 (MBP, myel in basic protein)がガングリオシドと反応する ことが報告されているが [Yohe，H.C.， Jacobson, R. I., and Yu, R.K. (1983) J. Neurosci. Res. $\underline{9}$, 401-402] 、本論文の著者 らは数々の証扢を挙げて、このガングリオシ ドレセプターはMBPでないことを示している。 更に著者らは脳の各部分をスライスして、 ${ }^{125}$ Iープローブとの結合をオートラジオグラフ ィーで調べているが、それは原著を見て戴き たい。細胞分画の実験から予想されるように、 
TIGG Vol.2 No.8 (1990)

\section{GLYOTOPIC (TIGG-11/02/90-GT-5)}

septohippocampal, and optic tracts as well as commissural structures such as the anterior commissure, corpus callosum, and pons where labeling is highest in contrast to the very weak labelling of gray mater tissue. Binding activity thus appears associated with the myelinated pathway in CNS. Further fractionation of brain membrane preparations indicated radioligand binding activity to be present in the myelinrich subfraction. However, the myelinated pathway of the peripheral nervous system (PNS) exhibited low binding activity both in purified PNS myelin and on autoradiography of tissue sections possibly due to functional differences between the myelin of CNS and PNS for maintaining axon outgrowth. The developmental expression of binding activity was concurrent with total myelin expression, showing profiles similar to those of a few myelin struc tural proteins such as proteolipid protein (PLP) and myelin basic protein (MBP), and periaxonal myelin proteins such as myelin-associated glycoprotein. Ganglioside receptors may possibly be essential to the developmental myelin process of axons. Radioligand binding activity continued to remain in a myelin preparation extracted with detergent to remove most MBP, PLP, myelin-associated glycoprotein, and other notable myelin proteins. The preliminary results show the ganglio side receptor to be a novel protein with a molecular weight of 200,000 by gel filtration chromatography. The discovery of this ganglioside receptor will undoubtedly provide much greater clarification of ganglioside functions in the nervous system.

Reported by Ji Li

Laboratory of Glycoconjugate Research, Mitsubishi Kasei Inst. of Life Sci. 
ミエリンを含む中枢神経にプロープとの強い 結合が示されている。

ガングリオシドのGT1bは軸索表面に多く、 オリゴデンドログリアのミエリン膜には殆ど 存在しないので、本論文の実験結果は、軸索 膜上のGT1bとミエリン膜上のガングリオシド レセプターが筑ansで結合していることを示し ている。

この二者の間の相互作用は、中枢神経が形 成される時の軸索とそれを取り巻くミエリン との相互の認識に必要な、静的反応なのだろ うか。それとも、コレラトキシンのサブユニ ットBがガングリオシドのGM1と反応する時に 細胞增殖が刺激されるような、動的反応を惹 き起こしているのだろうか。

界面活性剂であらかじめ処理してガングリ
オシドを抽出して除いておかないと、このレ セプターはプロープと反応しないことが知ら れているので、このレセプターは組織内で、 ガングリオシドと強く結合していると考えら れ、従って前者の役割を果たしているように 見受けられる。神経細胞は分化の後は分裂を しないと考えられているから、コレラ毒䒺の サブュニットBとGM1の反応のようなことは起 こらないだろうが、神経細胞膜上に豊富なガ ングリオシドは、その軸索を絶縁体として包 むミエリン膜で確実に包まれるためだけに、 役立っているのだろうか?

\section{三菱化成生命科学研究所 - 複合糖質研究室} 山形達也 